\title{
APTT (ACTIVATED PARTIAL THROMBOPLASTIN TIME) DAN (PROTHROMBIN TIME) PADA PENDERITA DIABETES MELITUS TIPE 2 DI RSUD dr. DORIS SYLVANUS PALANGKARAYA
}

\author{
APTT (Activated Partial Thromboplastin Time) and PT (Prothrombin Time) in Diabetes Mellitus Type 2 \\ in RSUD dr. Doris Sylvanus Palangkaraya \\ 1*Rinny Ardina, ${ }^{2}$ Fera Sartika, ${ }^{3}$ Lidya Prihatini Nainggolan \\ ${ }^{1,2,3}$ Universitas Muhammadiyah Palangkaraya, Jl. RTA. Milono Km. 1,5, Palangka Raya, Indonesia
}

*e-mail : rinyardina@gmail.com

\begin{abstract}
ABSTRAK
Penderita Diabetes mellitus tipe 2 (DMT2) memiliki risiko tinggi terhadap kejadian aterotrombotik. Kondisi hiperglikemia dan gangguan metabolik lain pada DMT2 berhubungan dengan abnormalitas sistem hemostasis dan trombosis yang berkontribusi terhadap penyakit kardiovaskular. Pemeriksaan laboratorium rutin untuk menilai sistem hemostasis ialah pemeriksaan Activated Partial Thromboplastin Time (APTT) dan Prothrombin Time (PT). Tujuan penelitian ini ialah untuk memberikan gambaran abnormalitas APTT dan PT pada penderita DMT2 di RSUD dr. Doris Sylvanus Palangkaraya. Sampel sebanyak 20 penderita DMT2 diperoleh dengan menggunakan teknik purposive sampling dan sampel darah diperiksa dengan alat koagulasi COATX Biosystem metode fotokolorimetri. Didapatkan hasil 70\% APTT memendek, 5\% APTT memanjang dan 25\% APTT normal. Sedangkan hasil PT didapatkan 25\% PT memendek dan 75\% APTT normal. Abnromalitas APTT dan PT pada penderita DMT2 di RSUD dr. Doris Sylvanus Palangkaraya menunjukkan abnormalitas sistem koagulasi sehingga memungkinkan kecenderungan perdarahan serta penyakit kardiovaskular pada penderita DMT2. Pemeriksaan koagulasi rutin sebaiknya dapat terus dilakukan untuk membantu manajemen diabetes mellitus yang lebih baik agar dapat mencegah komplikasi mikro atau makrovaskular.
\end{abstract}

Kata kunci : APTT, PT, diabetes mellitus tipe 2

\section{ABSTRACT}

Patients with type 2 diabetes mellitus (T2DM) have a high risk of atherothrombotic events. Hyperglycemia and other metabolic disorders in T2DM are associated with abnormalities of hemostasis system and thrombosis that contribute to cardiovascular disease. Routine laboratory tests to examine the hemostasis system are Activated Partial Thromboplastin Time (APTT) and Prothrombin Time (PT). This study aimed to describe the abnormalities of APTT and PT in patients with T2DM in RSUD dr. Doris Sylvanus Palangkaraya. Twenty subjects with T2DM in RSUD dr. Doris Sylvanus Palangkaraya were obtained using purposive sampling techniques and blood samples were examined with a COATX Biosystem coagulation using photocolorimetric method. This study found that was 70\% APTT are shortened, 5\% APTT are prolonged and $25 \%$ APTT were normal. While the PT results were 25\% PT are shortened and 75\% APTT were normal. Abnormalities of APTT and PT in T2DM patients in RSUD dr. Doris Sylvanus Palangkaraya showed an abnormality of the coagulation system so as to allow a tendency for bleeding and cardiovascular disease in T2DM patients. Routine coagulation test should be continued to help better diabetes mellitus management in order to prevent micro or macrovascular complications.

Keyword: APTT, PT, type 2 diabetes mellitus

\section{PENDAHULUAN}

Penderita diabetes mellitus memiliki risiko tinggi terhadap kejadian aterotrombotik. Banyak penelitian menunjukkan bahwa berbagai macam diabetes mellitus berhubungan dengan abnormalitas sistem hemostasis dan trombosis. Trombosis vena juga sering ditemukan pada penderita diabetes.
Delapan puluh persen penderita diabetes mellitus meninggal karena trombosis, dan $75 \%$ dari kematian ini disebabkan oleh komplikasi kardiovaskular dan dan $25 \%$ akibat disfungsi pembuluh darah perifer. Endotel pembuluh darah merupakan situs pertahanan utama terhadap trombosis dan disfungsi endotel pembuluh darah 
dilaporkan terjadi pada penderita Diabetes mellitus tipe 2 (DMT2) (Zhao et al., 2011).

Endotel pembuluh darah merupakan salah satu komponen utama dalam regulasi mekanisme hemostasis (koagulasi dan fibrinogen). Keadaan prokoagulan yang ditemukan pada penderita DMT2, secara langsung berkontribusi terhadap penyakit kardiovaskular. Faktor-faktor koagulasi seperti faktor I, VII, IX, XII, Kallikrein dan von Willebrand factor (VWF) diketahui meningkat pada penderita DMT2. Kejadian hiperkoagulabilitas dapat disebabkan oleh ketidakseimbangan antara permukaan endotel pembuluh darah dengan faktor-faktor koagulasi darah. Diketahui penderita DMT2 mengalami peningkatan antihemophilic factor (VIII) yang baru-baru ini diketahui berhubungan dengan disfungsi pembuluh darah. Beberapa penelitian melaporkan adanya insignifiknasi pada FVIII antara DMT2 dengan individu normal yang sehat. Peningkatan FVIII lebih biasanya disertai pula dengan peningkatan konsentrasi VWF (Bashir and Ali, 2018).

Peningkatan VWF terkait dengan adanya disfungsi endotel dan / atau proses inflamasi, karena VWF adalah protein fase akut yang disimpan dalam bentuk multimer di sel endotel. Sekitar 95\% dari faktor VIII (FVIII) bersirkulasi dalam plasma dengan terikat pada VWF dan 5\% beredar secara bebas. Kadar VWF plasma terutama terkait dengan sekresi sel endotel dan juga apabila terjadi peradangan sebagai respons terhadap aktivasi Tumor Necrosis Factor (TNF). Peningkatan kadar FVIII plasma dianggap sebagai faktor risiko independen terhadap tromboemboli. Selain itu, kondisi hiperglikemia pada DMT2 berkontribusi terhadap disfungsi endotel dan kerusakan pembuluh darah. Efek langsung dari hiperglikemia berdampak pada molekul fibrinogen. Glikasi fibrinogen akibat hiperglikemia menghasilkan pembentukan fibrin yang lebih padat dengan serat-serat halus yang resisten terhadap fibrinolisis sehingga menyebabkan pembentukan sumbat berlebih (trombosis) (McFarlane, 2017).

Kaskade koagulasi dapat diperiksa melalui pemeriksaan laboratorium hemostasis dengan dua tes koagulasi utama yaitu : prothrombin time (PT) dan activated partial thromboplastin time (APTT). PT mencerminkan defisiensi faktor-faktor koagulasi jalur ekstrinsik (misalnya tissue factor dan faktor VII), sedangkan APTT mencerminkan kelainan jalur intrinsik (kontak) (misalnya defisiensi faktor VIII, IX, IX, dan XII) (Lippi et al., 2010).

APTT umumnya digunakan untuk menguji faktor-faktor koagulasi jalur intrinsik, dimana APTT yang memanjang merupakan indikator adanya defisiensi pada salah satu faktor koagulasi atau adanya inhibitor koagulasi. Penelitian terbaru juga menunjukkan APTT memendek juga dapat mencerminkan ketidakseimbangan prokoagulan dibuktikan dengan peningkatan kadar dari faktor-faktor koagulasi. Karena itu, APTT bisa digunakan untuk menilai risiko komplikasi tromboemboli pada penderita diabetes mellitus (Zhao et al., 2011).

\section{METODE PENELITIAN}

\section{Jenis Penelitian}

Jenis penelitian yang digunakan adalah penelitian deskriptif yang bertujuan untuk membuktikan adanya perubahan APTT dan PT pada penderita Diabetes mellitus tipe 2 yang rutin melakukan pemeriksaan di Laboratorium Patologi Klinik RSUD dr. Doris Sylvanus Palangkaraya.

\section{Populasi dan Sampel}

Populasi yang digunakan dalam penelitian ini adalah penderita diabetes melitus tipe 2 yang rutin melakukan pemeriksaan di Laboratorium Patologi Klinik RSUD dr. Doris Sylvanus Palangkaraya. Pengambilan sampel dalam penelitian ini menggunakan non random sampling yaitu purposive sampling dengan kriteria inklusi ialah penderita Diabetes mellitus tipe 2 rawat jalan, menderita Diabetes mellitus tipe 2 lebih dari 5 tahun, tidak memiliki riwayat penyakit terkait faal hemostasis sebelumnya, dan bersedia menjadi responen. Kriteria eksklusi adalah penderita Diabetes mellitus tipe 2 rawat inap, penderita Diabetes mellitus tipe 2 kurang dari 5 tahun, memiliki riwayat penyakit terkait faal hemostasis, dan tidak bersedia menjadi responden. Jumlah sampel yang diperoleh sebanyak 20 orang dengan memenuhi kriteria inklusi. 
BJMLT

\section{Instrumen Penelitian}

\section{Lembar Panduan Pertanyaan}

Penelitian ini menggunakan instrumen penelitian berbentuk lembar panduan pertanyaan untuk membantu pengumpulan sampel yang terdiri dari pemantauan dan penatalaksanaan glukosa darah serta pertanyaan yag berhubungan dengan faal hemostasis dengan jumlah pertanyaan sebanyak 20 item.

2. Alat dan Bahan Pemeriksaan Laboratorium

a) Tabung vakum biru berisi sodium sitrat $0,9 \%$

b) Spuit $3 \mathrm{cc}$

c) Tourniquet

d) Alat koagulasi CoatX Biosystem

a) Mikropipet dan Tip

b) Kuvet CoatX

c) Stopwatch

d) TE Clot APTT - S

e) TE Clot PT $-\mathrm{S}$

f) TE Control N

g) Alcohol swab

h) Kapas kering

i) Plester luka

e) Sampel darah vena

f) Aquabidest

g) Tissue

\section{Analisis Data}

Data yang diperoleh dari lembar panduan pertanyaan dan hasil pemeriksaan APTT dan PT akan dideskripsikan dalam bentuk persentase (\%).

\section{HASIL DAN PEMBAHASAN}

\section{Karakteristik Sampel}

Karakteristik sampel yang digunakan berdasarkan jenis kelamin, usia, lama menderita, pola makan, olahraga dan komplikasi penyakit lain, sebagai berikut :

TABEL 1. Karakteristik Sampel berdasarkan jenis kelamin, usia, lama menderita, pola makan dan komplikasi penyakit pada penderita DM Tipe 2 di RSUD dr. Doris Sylvanus Palangkaraya.

\begin{tabular}{lll}
\hline Karakteristik Sampel & Frekuensi & Persentase (\%) \\
\hline
\end{tabular}

\begin{tabular}{lcc}
\hline Laki - laki & 6 & 30 \\
Perempuan & 14 & 70 \\
Usia & & \\
& 9 & 45 \\
$50-59$ tahun & 8 & 40 \\
$60-69$ tahun & 3 & 15 \\
$70-79$ tahun & & \\
Lama Menderita & & \\
& 10 & 50 \\
$6-10$ tahun & 6 & 30 \\
$11-15$ tahun & 4 & 20 \\
$>20$ tahun & & \\
Komplikasi Penyakit & 3 & 15 \\
& 0 & 0 \\
Hipertensi & 1 & 5 \\
Jantung Koroner & 16 & \\
Penyakit Ginjal & & \\
Tidak ada & \\
\hline
\end{tabular}

\section{Hasil Pemeriksaan APTT dan PT Pada Penderita DM Tipe 2 di RSUD dr. Doris Sylvanus Palangka Raya}

Hasil pemeriksaan APTT (Activated Parsial Tromboplastin Time) dan PT (Prothrombin Time) pada penderita diabetes melitus tipe 2 di Laboratorium Patologi Klinik RSUD dr. Doris Sylvanus Palangkaraya dapat dilihat pada tabel 2 berikut ini:

TABEL 2. Range Control yang Digunakan Pada Pemeriksaan APTT dan PT

\begin{tabular}{cccc}
\hline & & \multicolumn{2}{c}{ Nilai Control } \\
No. & Hari Ke & APTT & PT \\
& & $(\mathbf{2 4 , 5} \mathbf{s}-\mathbf{3 5 , 3} \mathbf{s})$ & $(\mathbf{1 1 , 2} \mathbf{~}-\mathbf{1 6 , 2} \mathbf{~ s})$ \\
\hline 1. & Hari Ke-1 & $34,9 \mathrm{~s}$ & $14,9 \mathrm{~s}$ \\
2. & Hari Ke-2 & $28,0 \mathrm{~s}$ & $13,4 \mathrm{~s}$ \\
3. & Hari Ke-3 & $30,1 \mathrm{~s}$ & $14,5 \mathrm{~s}$ \\
\hline
\end{tabular}

Tabel 2 menunjukkan range nilai control pada pemeriksaan APTT (Activated Parsial Tromboplastin Time) dan PT (Prothrombine Time), dari hasil tersebut menunjukkan bahwa range nilai controlnya masuk dalam range nilai control yang menjadi standar pada alat. Sehingga dapat dipastikan bahwa alat yang digunakan bagus dan hasil pemeriksaan valid.

TABEL 3. Hasil APTT Pada Penderita DM tipe 2 di RSUD dr. Doris Sylvanus Palangkaraya

\begin{tabular}{ccccccc}
\hline \multicolumn{4}{c}{ di RSUD dr. Doris Sylvanus Palangkaraya } \\
\hline \multicolumn{4}{c}{ APTT } \\
(Activated Parsial Tromboplastin Time) \\
\multicolumn{2}{c}{ Memendek } & \multicolumn{2}{c}{ Normal } & \multicolumn{2}{c}{ Memanjang } \\
N & $\%$ & N & $\%$ & N & $\%$ \\
\hline 14 & 70 & 5 & 25 & 1 & 5 \\
\hline
\end{tabular}


TABEL 4. Hasil PT Pada Penderita DM tipe 2

di RSUD dr. Doris SylvanusPalangkaraya PT (Prothrombin Time)

\begin{tabular}{cccc}
\multicolumn{2}{c}{ Memendek } & \multicolumn{2}{c}{ Normal } \\
$\mathbf{N}$ & $\%$ & $\mathbf{N}$ & $\%$ \\
\hline 5 & 25 & 15 & 75
\end{tabular}

Karakteristik diabetes salah satunya adalah risiko tinggi terjadinya komplikasi aterotrombotik yang dapat menyerang otak, jantung, dan juga pembuluh darah arteri perifer. Kondisi ini merupakan bentuk dari abnormalitas sistem hemostasis. Adanya disfungsi pada kaskade koagulasi seperti abnormalitas pada jalur intrinsik, jalur ekstrinsik, dan jalur bersama dapat meningkatkan aterogenesis pada penderita diabetes (Mohammed, 2020).

Pada penelitian ini kami menemukan 25\% APTT normal, 70\% APTT memendek, dan 5\% APTT memanjang pada penderita DMT2 yang menjadi subjek penelitian di RSUD dr. Doris Sylvanus Palangkaraya. Hasil serupa juga ditemukan oleh Ephraim et al. (2017) dimana APTT dan PT memendek secara signifikan pada 60 penderita DMT2 jika dibandingkan dengan kelompok kontrol (orang sehat) di Ghana. Begitu pula pada penelitian Mohammed (2020) dimana ditemukan APTT dan PT memendek pada penderita DMT2. Karim et al. (2015) menemukan nilai APTT dan PT signifikan lebih rendah pada penderita DMT2 di Dhaka dibandingkan dengan kelompok kontrol.

Sedangkan Elhassade \& Balha (2016) hanya menemukan nilai APTT yang signifikan lebih rendah pada penderita DMT2 di Libya dibandingkan dengan kelompok kontrol sedangkan PT normal. Hasil ini serupa dengan penelitian (Awad, Hassan and Babiker, 2016) yang juga menemukan APTT memendek sedangkan PT normal pada penderita DMT2.

APTT memanjang pada 5\% penderita DMT2 RSUD dr. Doris Sylvanus juga ditemukan pada penelitian lain seperti penelitian Abden \& Hamza (2015) yang menemukan APTT memanjang pada penderita DMT2 dan (Thukral et al., 2018) menemukan adanya peningkatan signifikan APTT pada DMT2 di Bathinda dibandingkan kelompok kontrol, sedangkan temuan lain yang tidak didapatkan dalam penelitian kami ialah pada penelitian (Thukral et al., 2018) didapatkan peningkatan yang signifikan PT pada penderita DMT2 dibandingkan kelompok kontrol.

Seluruh pasien DMT2 yang menjadi subjek dalam penelitian ini berada pasa rentang usia 50-79 tahun dan memiliki kadar glukosa darah puasa dan glukosa 2 jam post prandial yang tidak terkontrol (di atas nilai normal/hiperglikemia). Selain itu, $20 \%$ diantara pasien DMT2 ini telah mengalami komplikasi akibat DMT2 yang dideritanya. Kondisi hiperglikemia yang terjadi pada pasien DMT2 ini terus terjadi meskipun mereka rutin melakukan pemeriksaan laboratorium dan juga konsultasi ke dokter untuk terapi pengobatan di Poli Penyakit Dalam RSUD dr. Doris Sylvanus Palangkaraya.

Kondisi hiperglikemia persisten pada penderita DMT2 seperti yang terjadi pada subjek penelitian ini dapat menyebabkan kondisi koagulopati yang disebabkan oleh glikasi aemoglobin, protrombin, fibrinogen dan beberapa protein lainnya yang terlibat dalam mekanisme koagulasi (Ephraim et al., 2017). APTT merupakan indikator defek dari faktor-faktor koagulasi pada jalur intrinsik dan jalur bersama, sedangkan PT merupakan indikator defek faktorfaktor koagulasi pada jalur ekstrinsik dan jalur bersama (Mohammed, 2020).

APTT dan PT yang memendek pada penderita DMT2 menunjukkan kondisi hiperkoagulatif dimana ini berhubungan dengan peningkatan risiko trombotik dan risiko penyakit kardiovaskular pada penderita DMT2 (Ephraim et al., 2017 ; Awad, Hassan and Babiker, 2016). Selain itu, APTT dan PT yang memanjang yang ditemukan pada penderita DMT2 juga menunjukkan hal yang sama yaitu adanya abnormalitas dari mekanisme koagulasi sehingga memungkinkan kecenderungan perdarahan serta penyakit kardiovaskular pada penderita DMT2 (Thukral et al., 2018).

Namun dalam penelitian ini masih banyak keterbatasan diantaranya jumlah sampel yang sangat sedikit dan perlunya tambahan parameter pemeriksaan komponen koagulasi lainya seperti jumlah trombosit, indeks trombosit, International Normalised Ratio (INR), dan fibrinogen untuk menguatkan gambaran abnormalitas sistem koagulasi pada pasien DMT2 diRSUD dr. Doris Sylvanus Palangkaraya. 


\section{KESIMPULAN}

Dalam penelitian ini didapatkan nilai APTT dan PT yang abnormal pada penderita DMT2 di RSUD dr. Doris Sylvanus Palangkaraya. Adanya hasil yang abnormal pada mekanisme hemostastis membuktikan bahwa pemeriksaan koagulasi rutin sebaiknya dapat terus dilakukan untuk manajemen diabetes mellitus yang lebih baik agar dapat mencegah komplikasi mikro atau makrovaskular akibat gangguan koagulasi.

\section{DAFTAR PUSTAKA}

Abdeen, K. S. A., and Hamza, K. M. 2015. 'Prothrombin Time (PT) and Activated Partial Thromblastin Time (APTT) in Sudanese Diabetic Patients, Journal of Natural and Medical Sciences, 16 (1), pp. 17-24.

Awad, A., Hassan, A. and Babiker, L. 2016.'Assessment of some coagulation parameters ( PT , APTT , INR , PLTS COUNT and PLT indices ) in Sudanese Patients with Diabetic Type 2 January 2016', 4(2), pp. 1570-1585.

Bashir, B. A. and Ali, M. S. 2018. 'Hemostatic state augmented with platelet indices among Sudanese diabetic septic foot', $B M C$ Hematology. BMC Hematology, 18(1), pp. 510.

Elhassade, A. S., and Balha, O. S. 2016. 'Effect of Diabetes Mellitus Type II on Activated Partial Thromboplastin Time and Prothrombin Time', International Journal of Clinical and Biomedical Research, 2(3), pp. 1-4.

Ephraim, R. K., _Awuku, YA., Adu, P., Ampomah, LT., Adoba, P., Panford, S., Ninnoni, JP., Agbodzakey, H. 2017.'High risk of coagulopathy among Type-2 Diabetes Mellitus clients at a municipal hospital in Ghana', Ghana medical journal,
51(3), pp. 101-107.

Karim, F., Akter, QS., Jahan, S., Khanom, S., Haque, S., Yeasmin, T., Siddika, T., Sinha, S. 2015. 'Coagulation Impairment in Type 2 Diabetes Mellitus', Journal of Bangladesh Society of Physiologist, 10(1), pp. 26-29.

Lippi, G., Salvagno, GL., Ippolito, L., Franchini, M., Favaloro, EJ. 2010. 'Shortened activated partial thromboplastin time: Causes and management', Blood Coagulation and Fibrinolysis, 21(5), pp. 459-463.

McFarlane, S. I. 2017. 'Shift work and sleep: medical implications and management', Sleep Medicine and Disorders: International Journal, 1(2), pp. 1-14. doi: 10.15406/smdij.2017.01.00008.

Omer Ibrahim Abdallah Mohammed. 2020. 'Estimation of prothrombin time, activated partial thromboplastin time and thrombocytes among Sudanese patients with diabetes', GSC Biological and Pharmaceutical Sciences, 10(1), pp. 034-038.

Thukral, S., Hussain, S., Bhat, S., Kaur, N., Reddy, A. 2018 'Prothrombin Time (PT) and Activated Partial Thromboplastin Time (APTT) in Type 2 Diabetes Mellitus, a Case Control Study', International Journal of Contemporary Medical Research, 5(8), pp. H5-H9.

Zhao, Y., Zhang, J., Zhang, J., Wu, J. 2011. 'Diabetes mellitus is associated with shortened activated partial thromboplastin time and increased fibrinogen values', PLOS ONE, 6(1), pp. 4-7. 